\title{
An Analysis of Public Participation in E-Musrenbang (Planning Development Discussion) As An Effort to Support The Successful Performance of Tanjung Priok District Jakarta
}

\author{
$1^{\text {st }}$ Mary Ismowati ${ }^{1}, 2^{\text {nd }}$ Hendra Brajanegara ${ }^{2}, 3^{\text {rd }}$ Murni Sianturi $^{3}, 4^{\text {th }}$ Yuliyanto $^{4}$ \\ \{mary.ismowati@stiami.ac.id ${ }^{1}$, braja@gmail.com ${ }^{2}$, murnisianturi70@gmail.com ${ }^{3}$, \\ Yuliyantosap8@gmail.com\} \\ Magister Program of Administrative Sciences, Institut Ilmu Sosial dan Manajemen STIAMI \\ Jakarta $1,2,3,4$
}

\begin{abstract}
There are still many problems in the implementation of e-Musrenbang in Tanjung Priok Sub-District, including passive participation of the community, lack of socialization to the community, minimal community knowledge about e-Musrenbang, not yet professional staff, inaccurate planning implementing e-Musrenbang, a pluralistic community culture organization and a short implementation time. The research used qualitative method by interviewing the informant from variety qualifications and ability in the field of e-Musrenbang. Based on analysize shows that the implementation of eMusrenbang in the Tanjung Priok sub-district is dependent on the participation of the community who know the conditions and needs themselves, and also community who participate in planning and accessing the input of the e-Musrenbang application. The Tanjung Priok Urban sub-district government, is only a facilitator and coordinator of the development planning activities. Community participation in the e-musrenbang program has been quite good, only the constraints in the field are due to ignorance of some people to the e-musrenbang system so that they are more willing to do it manually, so the results of implementation are hampered. E-Musrenbang still does not support the implementation of these activities, and the weak coordination between implementers of e-Musrenbang, it also greatly influences the success of the e-Musrenbang itself..
\end{abstract}

Keywords: Public Participation, E-Citizen Planning, E-Musrenbang, Performance.

\section{Introduction}

As a result of the decentralized government system or regional autonomy in accordance with Law No. 9 in 2015 about Regional Government, the development process must apply the principles of decentralization, bottom up from community, and active participation of the community.

Communities better understand their needs and problems, which must be empowered so that they are better able to recognize their needs, formulate plans and implement development independently and independently (Talen 2000; Pal 2000; Fadil 2013; Koontz 2014). The impact of the top-down development approach that has been implemented by the government with full power is in the central government, causing regional governments to be unresponsive and less sensitive to the aspirations of the community 
Area. As a result, it is not uncommon for development plans that have been compiled and implemented by the government not in accordance with the needs of the community. Development planning must not ignore democratic principles such as deliberative models or democratic models in public policy formulation (Abelson, 2003; Nugroho, 2015).

The Tanjung Priok sub-district of North Jakarta Administration has implemented this decentralization policy by implementing development in various sectors in accordance with the plans set by the Governor of DKI Jakarta Province. The activity involved RW level officials who contributed through the Development Planning Consultation (Musrenbang), the aim of which was to improve the welfare of the community. Determination of development programs involves community participation. This is bottom-up planning (Pal, 2006). Increasing community participation is one form of community empowerment (Fraser 2006; Tulooch 2007; Fadil 2013).

The need for community participation in the Tanjung Priok sub-district is due to the lack of optimal development carried out by the North Jakarta Administration City Government. The results of the development carried out by the Tanjung Priok sub-district are a representation of the Tanjung Priok sub-district's Performance. Based on observations, the services provided by the Tanjung Priok village government showed that there were still complaints from the community both directly and indirectly on the performance of the Kelurahan. This can be seen from the low work productivity and discipline of these employees, and the lack of adequate work facilities.

The lack of optimal development carried out by the Tanjung Priok Urban Village is illustrated by variousproblems and the results of development evaluation as from the results of studies in the field presented as in the following table:

Table 1.1 Tanjung Priok sub-district's Performance Program Evaluation in 2017

\begin{tabular}{|l|l|c|l|l|}
\hline No & Item & Target & Realization & Average (\%) \\
\hline 1 & Economic sector & $90 \%$ & $69 \%$ & 21 \\
\hline 2 & Health sector & $95 \%$ & $73 \%$ & 22 \\
\hline 3 & Education sector & $90 \%$ & $67 \%$ & 23 \\
\hline 4 & Envorinmnet sector & $95 \%$ & $70 \%$ & 25 \\
\hline & Average & & & 23 \\
\hline
\end{tabular}

Source : research in 2017

From the data above shows that the evaluation of development results in accordance with the use of the budget has not entirely met the target

Community participation is the participation of the community in the process of identifying problems and potential that exist in the community, selection and decision making about alternative solutions to deal with problems, implementing efforts to overcome problems, and community involvement in the process of evaluating changes that occur. (Adi, 2005: 27).

Development planning discussion (Musrenbang) Kelurahan is an annual discussion forum and dialogical forum between the government and stakeholders of an issue / issue, policy, regulation, or development program being discussed. stakeholders agree on an activity plan for the next fiscal year by referring to the Regional Medium Term Development Plan (RPJMD) that has been prepared for the next 5 years, and is carried out every January.

In accordance with technological developments, digital communities seek and obtain information from different places, no longer in the conventional way. Government planning must adapt these conditions to meet community needs (Staffans, 2010). For this reason, eMusrenbang (electronic- Musrenbang) is used on an online network, to facilitate and 
accelerate the implementation of Musrenbang in capturing the aspirations of the community's proposals. Community participation in online development planning has also been carried out in many countries (Conroy, 2010; Staffans, 2010; Kubicek, 2010, Fikri 2015; Sholihmu'adi 2015)

From the observations there are still many problems in the implementation of eMusrenbang in Tanjung Priok Sub-District, including passive participation of the community, Lack of socialization to the community, minimal community knowledge about e-Musrenbang, not yet professional staff, inaccurate planning implementing e-Musrenbang, a pluralistic community culture organization and a short implementation time. From the various descriptions above, the author conducted a study with the title: "Analysis of Community Participation in e-Musrenbang as an Effort to Support the Success of the Tanjung Priok sub district's Performance Program"

The purpose of this study is to analyze community participation in e-Musrenbang, and any obstacles faced in implementing community participation in e-Musrenbang as an effort to support the success of the Tanjung Priok sub -district's performance program.

\section{Public Participation}

According to Verhagen (1980) "participation is a form of participation or involvement of someone (individual or citizen) in a particular activity". The participation or involvement referred to here is not passive but actively directed by the person concerned. Therefore, participation will be more precisely interpreted as the participation of a person in a social group to take part in the activities of their community, apart from their own work or profession.

Citizen involvement in the broad sense should be encouraged both through regulation and the creation of an ideal climate of democratization in the region. Thus, it will increasingly have a growing sense of community to the programs area (Satries, 2011).

Sherry R Arnstein cited by Connor (1988) and Sigit (2013) divides the level of community participation in government development programs into eight levels of community participation based on the power given to the community, as follow :

1. Citizen control, the community can participate in and control the entire decision-making process.

2. Delegated power, at this level the community is given an abundance of authority to make decisions on certain plans.

3. Partnership, the community has the right to negotiate with the decision makers or the government, on a joint agreement the power is divided between the community and the government.

4. Placation, the power holder (government) needs to appoint a number of people from the affected part of society to become members of a public body.

5. Consultation, the community is not only notified but also invited to share opinions, even though there is no guarantee that the opinions expressed will be taken into consideration in decision making.

6. Informing, the power holders only provide information to the public regarding the proposal of activities, the community is not empowered to influence the results.

7. Therapy, power holders give reasons for proposals by pretending to involve the community. 
8. Manipulation, is the lowest level of participation, where the name is only used by the community.

Furthermore Arstein divides the 8 levels of participation into 3 Ladder (Connor: 1998); Sigit: 2013), namely:

1. there is no participation at all (non participation), which includes manipulation and therapy.

2. community participation in live forms accepts several degrees (tokens of tokenism), including informing, consultation and placation,

3. community participation in the form of having power (degrees of citizen power), including partnership, delegated power, and citizen power

\subsection{E- Musrenbang (Development Planning Discussion)}

Development Planning Discussion (Musrenbang) is a forum for communication or deliberation of development plans carried out by a group of community and government in a region for the successful of development programs, discussing the problems they face and deciding short-term development priorities, then proposing to the government at a more level high, and through a planning agency (BAPPEDA). Musrenbang in the kelurahan was held during January.

e-Musrenbang is a website \& mobile apps-based planning application developed by the Regional Development Planning Agency (BAPPEDA) of the DKI Jakarta Province with the aim of supporting the implementation of Musrenbang in the preparation of Local Government Work Plans (RKPD), and as a media for public aspirations, verifying (existing condition / field) and publish the results of the community's aspirations in the form of web and mobile applications, with the website address http://musrenbang.jakarta.go.id. and will lead to ebudgeting.

Sub-distric's Musrenbang Process

1. Pre-sub district's Musrenbang

2. Implementation of the district's Musrenbang

In the implementation of the district's Musrenbang, the Team is: district's Head, Chairperson and members of the LPM, Sub-district and District officials, Head of school, Head of puskesmas, Officials of the district's, and NGO in the district.

While the participants of the district's Musrenbang are all components of the community in the district's.

3. Post-Musrenbang: to make a List of Priorities for the Issues of Urban district's Development

\subsection{Sub-district's performance}

Organizational performance is defined as the effectiveness of the organization as a whole to meet the defined needs of each group with regard to systematic efforts and to increase the organization's ability to continually achieve their needs effectively Nasucha (2004); Sinambela (2012). Wibowo (2011: 229) explained that the measurement of performance needs to be done to find out whether during the implementation of the performance there is a deviation from the predetermined plan, or whether the performance can be carried out according to the schedule specified, or whether the performance results have been achieved

as expected. Kelurahan performance is evaluated to the extent that the main tasks in the development area of the Kelurahan are able to carry out in accordance with their authority. 
Dwiyanto in Pasolong (2013: 178) describes several indicators used to measure the performance of public bureaucracy, namely: Productivity, Quality of Service Responsiveness, Responsibility, and Accountability

Mahsun (2006: 31) public sector organizations require a broader measure of performance assessment, not only measuring financial levels and efficiency levels. The measurement of the performance of public sector organizations includes 6 aspects as follows: Input groups, process groups, output groups, outcome groups, benefit groups and impact groups

This study used performance indicators according to Mahsun in assessing the performance of sub-district's organizations

\section{Research Methods}

Qualitative approaches is used in research Sampling or data sources in this study were conducted purposively. Collection techniques with triangulation (combined), qualitative data analysis and research results emphasizing the meaning of generalization. Determination of informants is carried out snowball sampling. Focus on community participation in the implementation of e-Musrenbang in the area of sub-ditrict Tanjung Priok Jakarta.

The informants are :1. The Tanjung Priok sub-ditrict's Head has worked for more than 15 years in the North Jakarta Administrative City as a sub-ditrict's Head so that it is credible.2. Representative of the RW Management, so that they are expected to be able to answer the questions asked 3. Community leaders, as people who have participated in the Kelurahan Musrenbang, so researchers are confident of their ability to answer the questions asked

\section{Data analysis technique}

The analysis technique used is Interactive Miles and Huberman (1994), commonly referred to as interactive models, which basically consist of three components: data reduction (data reduction), data presentation (data display), and drawing and verifying conclutions ) The technique of checking the validity of the data obtained is based on certain criteria. There are four criteria used in checking data validity: (1) credibility; (2) transferability; (3)dependence; and (4) certainty (Guba: 2002). The research was conducted in Tanjung Priok Sub-District, which is a Regional Work Unit in the DKI Jakarta Province, especially in the Administrative City of Jakarta, which is held for 3 (three) months from November 2017 to January 2018.

\section{Results And Discussion}

The Tanjung Priok sub-district has an overall area of 559 hectares, including in Indonesia Port II (PELINDO) covering an area of \pm 469 ha, offices / trade and warehousing. There is the Tanjung Priok International Seaport, making Tanjung Priok Urban Village one of the International Gates to enter Jakarta from the sea. There are 158 RT (Neighborhood Unit) and 16 RW (Community Unit) with a population in December 2016 which is 41,290 people with an average population density of 73.86 people / $\mathrm{Km} 2$. follows:

Secondary data on the implementation of the Musrenbang as presented in the table: 1 as 
Table 1.2 List of Proposed Results of Musrenbang in Tanjung Priok Sub-District 2016 \& 2017

\begin{tabular}{|l|l|l|l|l|}
\hline No & Year & No of Proposal & Acepted & Rejected \\
\hline 1 & 2016 & 186 & 130 & 56 \\
\hline 2 & 2017 & 101 & 97 & 4 \\
\hline
\end{tabular}

Source : research 2017

From table 1.2 above, there are 186 proposals for development activities and community empowerment activities. 130 proposed activities received in the SKPD Work Plan. 56 proposed activities that were rejected. in the 2017 Tanjung Priok Urban Village Musrenbang, 101 proposals for development and community empowerment activities, 87 proposed activities were received or accommodated in the SKPD Work Plan and 4 proposed activities were rejected. Based on the proposed data above, the proposed activity that was rejected was found, meaning that the community proposal could not be accommodated. Based on the results of verification of the Technical Service Team, there are proposals that do not match the designation, the number of incorrect volumes, and the location of the activity is unknown.

\section{Implementation of community participation in e-Musrenbang as an effort to support the success of the Tanjung Priok Urban Village program.}

Prior to the implementation of the Musrenbang, the Tanjung Priok sub-ditrict was held a community meeting at the Rukun Warga (RW) level, is called Rembug $R W$. The results of the proposals will be the source in the Development Planning Discussion (Musrenbang) at Tanjung Priok Sub-District.

"Community participation is community participation in the identification and potential processes that exist in the community, selection and decision making about alternative solutions to deal with problems in efforts to overcome problems and community involvement, and basically the community is still enthusiastic about organizing musrenbang, although there are some pessimistic about the musrenbang proposal ". (interviewed with Head of Tanjung Priok sub-district, 2017)
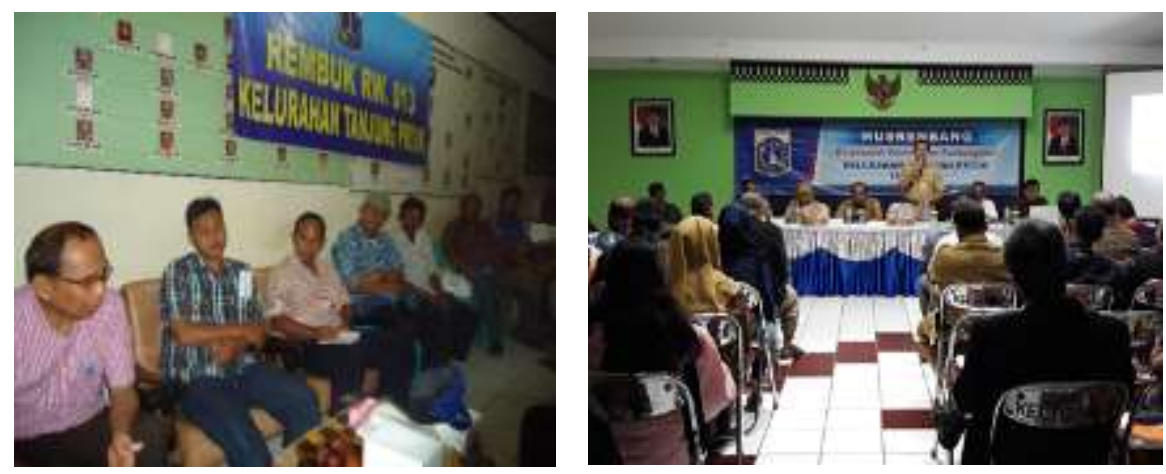

Figure 1

All the results of the proposed activities in the RW rembug are input into the eMusrenbang system by the operator from the RW element accompanied by the LMK RW and guided by the Rembug RW Companion Team (Tanjung Priok Village Staff). The result of the implementation of the Rembug RW is that all community aspirations have been inputted into 
the e-Musrenbang system. Then the RW Chair reported the results of the Rembug RW to the Lurah. Then verification by the Rembug RW Team (Tanjung Priok Urban Village Staff). Then the Stage of Implementation of the Kelurahan Musrenbang Forum led directly by the Tanjung Priok sub-district's Head.

This e-Musrenbang system is made user friendly, so that it is hoped that the community can operate easily. But there are still people who do not understand about inputting eMusrenbang, this is because of the lack of socialization to the community regarding the mechanism of the e-Musrenbang system. This also happens in other regions, such as the Kubicek study (2010); Fadil (2013); Fikri (2015); Hertiari (2015)

Another problem which is an obstacle is the lack of coordination between the Sectoral Technical Office to the Kelurahan regarding the proposed musrenbang addressed to the relevant SKPD, so that the musrenbang proposal is not accommodated

2. From the above description, it can be concluded that the constraints of the implementation of community participation in the e-Musrenbang of Tanjung Priok sub-district are as follows:

1. The facilities owned by the RW Management in the implementation of e-Musrenbang still do not support the implementation of these activities.

2. Community participation in Tanjung Priok Sub-District in Rembug RW and Kelurahan e-Musrenbang.still passive

3. Lack of socialization to the community to implement community participation in eMusrenbang

4. Lack of coordination between e-Musrenbang implementers.

5. The implementation time is felt to be short so that the preparation of the development plan becomes rushed and inaccurate

3. The Efforts That Can Be Made to Realize The Success Of E-Musrenbang In Tanjung Priok Village Are As Follows:

1. The Regional Government, especially the Tanjung Priok Sub-District, must conduct socialization / technical guidance on e-Musrenbang to the community in a regular and sustainable manner.

2. encourage the community Tanjung Priok Urban Village is directly involved actively participate in the organization of Rembug RW and Kelurahan e-Musrenbang.

3. Increasing the performance and professionalism of Tanjung Priok Sub-district employees, especially understanding and expertise in the area of Regional Development Planning.

\section{Conclusions}

\subsection{Conclusion}

The author can conclude as follows:

The implementation of e-Musrenbang in the Tanjung Priok sub-district is dependent on the participation of the community who know the conditions and needs, and those who participate in planning and accessing the input of the e-Musrenbang application are also the people themselves. The regional government, especially the Tanjung Priok Urban Village, is only a facilitator and coordinator of the development planning activities. 
Community participation in the e-musrenbang program has been quite good, only the constraints in the field are due to ignorance of some people to the electronic musrenbang (emusrenbang) system so that they are more willing to do it manually, so the results of implementation are hampered. Musrenbang still does not support the implementation of these activities, and the weak coordination between implementers of e-Musrenbang, it also greatly influences the success of the Kelurahan Musrenbang itself.

\subsection{Suggestion}

Suggestions for the Tanjung Priok Urban sub-district in the implementation of eMusrenbang in the next year are as follows:

1. Tanjung Priok Sub-District's employees to be more optimal in disseminating information on procedures and benefits from electronic use of Musrenbang (e-Musrenbang)

2. Encouraging the enthusiasm of the community to participate in the Musrenbang for the success of the Tanjung Priok Village performance program, because the purpose of eMurenbang is to involve the community members in the implementation of the Musrenbang for development and welfare in their own community.

\section{Acknowledgements}

Thank you for Prof.Dwi Purwoko; Dr.Taufan Maulamin.SE.Ak.MM, and my collegues at master Degree of Adminstrative Sciences Institut STIAMI.

\section{References}

[1]. Abelsona, Julia, Pierre-Gerlierforest ${ }^{\mathrm{b}}$, etc, 2003, Deliberations about deliberative methods: issues in the design and evaluation of public participation processes, Social Sciences and Medicine,Vol: 57 July $2003: 239-251$

[2]. Ahmad Mustanir, 2017, Community Participation In Development Plan Discussion ( Musrenbang) In Kelurahan Kanyuara Kecamatan Watang Sidenreng Sidenreng District Rappang , Jurnal Politik Profetik, Vol 5 No.2, 2017

[3]. Arnstein, Sherry R, 1969, A Ladder of Citizen Participation, JAIP Vol: 35 (4), July 1969.

[4]. Azhar, Fikri. 2015. Community Participation in the Development Planning Discussion (MUSRENBANG) in Pegiriansun-district, Semampir District, Surabaya City. ISSN 2303 - 341X, Volume 3 (2), Mei-Agustus 2015.

[5]. Bizjak, Igor , 2012, Improving public participation in spatial planning with Web 2.0 tools Improving public participation in spatial planning with Web 2.0 tools, Social Sciences, Published by: Urbanistični inštitut Republike Slovenije central and eastern euepean on line library.

[6]. Connor , M Desmond, 1988, A New Ladder of Citizen Participation , National Civic Review Vol: 77 (3),

[7]. Conroy Maria and Jennifer Evans-Cowley,2006, E-Participation in Planning: An Analysis of Cities Adopting On-Line Citizen Participation Tools, First Published June 1, 2006 Research International Journal of Environment and Pollution, https://doi.org/10.1068/c1k

[8]. Dea Deviyanti, 2013, Study On Community Participation In Development In Kelurahan Karang Jati Kecamatan Talah Balikpapan, eJournal Administrasi Negara, 2013, 1 (2): 380-394 ISSN 0000-0000, ejournal.an.fisip-unmul.org

[9]. Fadil, Fathurrahman. 2013. Community Participation in Development Planning Deliberations in Kota Baru Tengahsub-district. Journal of Political Science and Local Government, Volume II (2), Juli-Desember 2013.

[10]. Fraser, Evan D.G.2005, Bottom up and top down: Analysis of participatory processes for sustainability indicator identification as a pathway to community empowerment and sustainable environmental management, Journal of Environmental Management, Vol; 78 (2), 2006

[11]. Gene Rowe and Lynn J. Frewer. 2004. Evaluating Public-Participation Exercises : A Research 
Agenda. Hertiari Idajati, Adjie Pamungkas, Vely Kukinul S,Ummi Fadlillah,Fendy Firmansyah, Nursakti AP, Karina Pradinie. 2015. Increasing community knowledge of planning process and online Musrenbang process in Rungkut District Surabaya.

[12]. Hasibuan, Malayu. 2006. Basic Organization and Motivation for Increased Productivity, Jakarta: Bumi Aksara.

[13]. Ife, J dan Tesoriero, F. 2008. Alternative Community Development in the Era of Globalization: Community Development. Yogyakarta: Pustaka Pelajar.

[14]. Jones, Charles.O. 2004. Introduction to Public Policy Translation of Ricky Istamto. Jakarta : Roja Grafindo Persada.

[15]. Kanudia, Amit , Advanced Bottom-up Modelling for National and Regional Energy Planning in Response to Climate Change*, GERAD and McGill University

[16]. Koontz Tomas M. and Jens Newig. 2014, From Planning to Implementation: Top-Down and Bottom-Up Approaches for Collaborative Watershed Management, Policies studies journal vol:42 (3).

[17]. Mahsun, M. 2006. Public Sector Performance Measurement, Yogyakarta:BPFE- UGM.

[18]. Mitchel,T.R dan Larson. 1987. People and Organization : An Introducing to Organizational Behavior. Singapore: Mc Graw Hill Inc.

[19]. Pal ,Anirban , 2006, Scope for bottom-up planning in Kolkata: rhetoric vs reality, First Published October 1, 2006 Research Article, https://doi.org/10.1177/0956247806069628

[20]. Rivai, Veithzal. 2004. Company Human Resource Management, Jakarta: PT Raja Grafindo Persada.

[21]. Suwatno dan Donni Juni Priansa. 2011. HR Management in Public and Business Organizations. Bandung: Alfabeta.

[22]. Sigit Wijaksono, 2013, Effect of Length of Stay on the Level of Community Participation in Environmental Management of Settlements, BINUS, Vol 4 (1) , 2013, DOI: https://doi.org/10.21512/comtech.v4i1.2679

[23]. Slamet,2011 Pembangunan Masyarakat Berwawasan Partisipasi, (Surakarta: Sebelas Maret University Press), Hal.7.

[24]. Sholihmu'adi, Dr. 2015. The Dynamic of Musrenbang Implementation with E-Musrenbang System.

[25]. Satries Wahyu Ishardino, 2011, Measuring the Level of Community Participation in the City of Bekasi in the Preparation of Regional Budgets through the Implementation of Musrenbang 2010, Kybernan ( jurnal Ilmu Pemerintahan), Vol: 2 (11)

[26]. Silva , Carlos Nunes, 2010. Handbook of Research on E-planning ICT's for Urban Development and Monitoring, Information Sciences References, USA.

[27]. Talen, Emily, 2007,Bottom-Up GIS A New Tools for Individual and Group Expression in Participatory Planning, Journal of The America Planning Association, VoL 66 (3) , 2000, Pages 279-294 | Published online: 26 Nov 2007

[28]. Tulloch ,David L, 200Y. Many, many maps: Empowerment and online participatory mapping, Vol :12 (2). USA: Chicago University Library, ISSN 1390-0466

[29]. Verhagen, K, 1980, How to promote people's participation in rural development through local organization, Journal article: Review of International Co-operation 1980 Vol.73 (1).

\section{Document :}

[1]. Governor Decree No. 113 of 2017. Concerning Determination of Proposed Standards for 2017 Jakarta Province RW Consultation Activities in the framework of drafting Regional Government Work Plans, for 2018.

[2]. Governor Regulation Number 251. 2014. Regarding the Organization and Work Procedures of the Kelurahan.

[3]. Law No. 9. Year 2015. Regarding Regional Government.

[4]. http://musrenbang.jakarta.go.id/

[5]. https://bappeda.jakarta 